\title{
DISPLACEMENTS RECORDED ON CONTINUOUS GPS STATIONS FOLLOWING THE 2014 M6 CEPHALONIA (GREECE) EARTHQUAKES: DYNAMIC CHARACTERISTICS AND KINEMATIC IMPLICATIONS
}

\author{
${\text { Athanassios } \text { GANAS }^{1}{ }^{1} * \text {, Flavio CANNAVO }}^{2 \text { ), }}$, Konstantinos CHOUSIANITIS ${ }^{1 \text {, }}$ \\ Ioannis KASSARAS ${ }^{3)}$ and George DRAKATOS ${ }^{1)}$ \\ ${ }^{1)}$ Institute of Geodynamics, National Observatory of Athens, 11810 Athens, Greece, aganas@noa.gr, chousianitis@noa.gr, g.drakat@noa.gr \\ 2) INGV, Catania, Italy, flavio.cannavo@ct.ingv.it \\ 3) Department of Geology, University of Athens, kassaras@geol.uoa.gr \\ *Corresponding author's e-mail: aganas@noa.gr
}

\section{ARTICLE INFO}

Article history:

Received 12 September 2014

Accepted 5 January 2015

Available online 3 March 2015

\section{Keywords}

GPS

Strain

Earthquake

Strike-slip

Cephalonia

Greece

\begin{abstract}
We report cm-size dynamic displacements of continuous GPS stations onshore the island of Cephalonia, Ionian Sea, Greece, following the passage of seismic waves from two (2) shallow earthquakes on Jan 26, 2014 and Feb 3, 2014, respectively. First, we estimated the displacements from the high-rate GPS data collected at NOA station VLSM, near to the epicenters, by using state-of-art data processing strategies. The time series of displacements were analyzed both in time and frequency domains. From the dynamic analysis of $1 \mathrm{~Hz}$ data it is shown that the second event was recorded at station VLSM with higher amplitudes on both horizontal components, despite its smaller $(22 \%)$ moment magnitude, possibly due to its shallower depth. The static field of deformation is characterized by $\mathrm{cm}$-size permanent motion in opposing directions between stations KIPO (western Cephalonia) and VLSM (eastern Cephalonia), in agreement with the right-lateral kinematics of both ruptures. The $7.4 \mathrm{~cm}$ northward motion of station KIPO implies that the western peninsula of Cephalonia island (Paliki) belongs to a separate crustal block with respect to the rest of the island. The northward motion of KIPO also implies that the Cephalonia Transform Fault (CTF) did not rupture during the 2014 events, because KIPO is located at the hanging wall of CTF. It is possible that the amount of accumulated strain along CTF since $1983(\mathrm{M}=6.8)$ can be released by a seismic event of M6.5-6.7, at any time.
\end{abstract}

\section{INTRODUCTION}

On Jan. 26 and Feb 3, 2014 Cephalonia island, Ionian Sea, Greece, was struck by two strong, shallow earthquakes (Table 1; Karastathis et al., 2014; Papadopoulos et al., 2014; Valkaniotis et al., 2014; NOA moment magnitudes 6.0 and 5.9, respectively). The earthquakes ruptured at least two, 10+ $\mathrm{km}$ long, strike-slip faults (Valkaniotis et al., 2014; Boncori et al., 2015). According to the NOA Institute of Geodynamics (www.gein.noa.gr) the epicentre of the first event (Fig. 1; NOA web report) was located near the town of Argostoli (the capital), while the second one was located in the north Paliki Peninsula, about $10 \mathrm{~km}$ to the NW of the former. During both earthquakes, ground-shaking phenomena such as liquefaction, road failures, rock falls, small/medium size landslides and stonewall failures were widespread all over the western part of the island (Valkaniotis et al., 2014). No primary, surface fault breaks were observed. Both earthquakes occurred in response to ENE-WSW horizontal strain in central Ionian Sea (Hollenstein et al., 2008a; Ganas et al., 2013).

Continuous GNSS (Global Navigation Satellite Systems) networks deployed over the last twenty years to study kinematic deformation of the crust have been recently used to estimate epoch-wise displacements during moderate $(5<\mathrm{M}<7)$ to large $(7<\mathrm{M}<9.3)$ earthquakes (e.g. Larson et al., 2003; Hollenstein et al., 2008b; Avallone et al., 2011; Wright et al., 2012). Thanks to their improvements in accuracy (now of the order of millimeters, see Elósegui et al., 2006) and their high sampling rate (up to $50 \mathrm{~Hz}$, see Genrich and Bock, 2006) GNSS stations are increasingly becoming important tools, not only for geodesists but also for seismologists. The capability of GNSS permanent networks for seismological observations was proposed by Hirahara et al. (1994), Ge et al. (2000) and Larson (2009). There already exists a significant bibliography on this topic and a number of large earthquakes have been already recorded by High-Rate GPS (HRGPS) stations such as the 2002 M7.9 Denali earthquake (Kouba, 2003; Larson et al., 2003; Bock et al., 2004; Bilich et al., 2008), the M8.3 Tokachi-Oki and the M6.5 San Simon earthquakes in 2003 (Miyazaki et al., 2004; Ji et al., 2004; Langbein and Bock, 2004; Emore et al., 2007; Wang et al., 2007; Larson and Miyazaki, 2008; Melgar et al., 2011; Crowell et al., 2012), the M9.3 Sumatra earthquake in 2004 (Ohta et al., 2006), the 2008 M8.0 Sichuan earthquake (Shen et al., 2009; Shi et al., 2010), the 2009 M6.3 L'Aquila earthquake (Avallone et al., 2011), the M9.0 Tohoku-Oki 


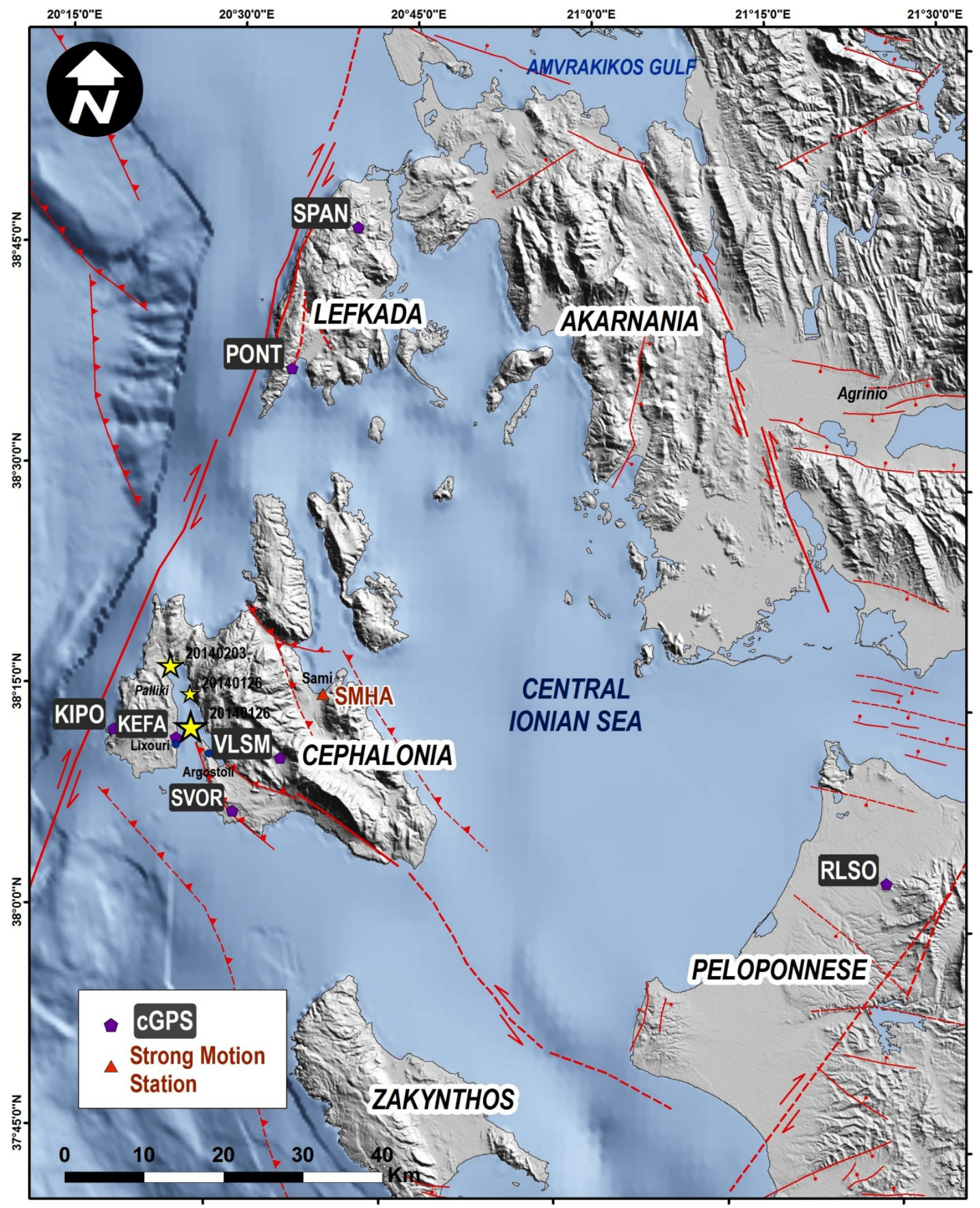

Fig. 1 Location map showing locations of continuous GPS stations (purple dots), the epicentres (yellow stars) of the two mainshocks and one aftershock of Jan 26, 2014 at 18:45 UTC. Red lines are active faults (dashed are inferred), arrows indicate sense of motion. Map modified from Valkaniotis et al. (2014). 
earthquake in 2011 (Grapenthin and Freymueller, 2011; Sato et al., 2011; Guo et al., 2013) and the 2013 M6.6 Lushan earthquake (Lou et al., 2014).

The Cephalonia earthquake displacements were recorded by several continuous global positioning system (cGPS) stations of NOANET (www.gein.noa.gr/gps.html; Ganas et al., 2011, 2014; Figure 1). All stations were operating with a sampling frequency of $1 \mathrm{~Hz}$. Stations VLSM, SPAN and PONT are equipped with a LEICA GRX1200PRO receiver and AX1202 antenna and were functioning during both earthquakes. Station KIPO is equipped with a LEICA GMX902GG receiver and AX1203+GNSS antenna, but, during the period of seismic unrest it was not functioning after lightning damage. Station VLSM is located about $11 \mathrm{~km}$ to the east of the epicentre of the Jan 26, 2014 event and $18 \mathrm{~km}$ to the SE of the Feb 32014 event (Fig. 1). In addition, the sampling frequency of the station VLSM was operating at $5 \mathrm{~Hz}$ thus recording the coseismic displacements produced by the Jan 26, 2014, earthquake at higher frequency. In the present study, after the description of the high-rate GPS (HRGPS) data analysis, we will show and compare results for both earthquakes for the near-field station VLSM. Then, we will compare the displacements recorded by the HRGPS (1 Hz up to $5 \mathrm{~Hz}$ ) at VLSM station and the strong-motion time histories $(100 \mathrm{~Hz})$ at NOA strong motion station SHMA, where the different instruments were approximately co-located (SHMA is located $9.7 \mathrm{~km}$ to the NE of VLSM; Figure 1). We also present results from 30-s GPS observations and use this data to test an Okada-type model of the January 26, 2014 dislocation.

\section{HIGH-RATE GNSS DATA PROCESSING}

In this study high-rate data from three continuous GPS stations equipped with Leica dualfrequency receivers and geodetic antennas were processed in kinematic Precise Point Positioning (PPP) mode. The available GPS data were sampled at $1 \mathrm{~Hz}$ and for the day of the first earthquake (i.e. 26 January 2014), the VLSM station was also sampling at $5 \mathrm{~Hz}$. Although, in the near field, and for a low to moderate earthquake, the HRGPS time series of displacements sampled at rates smaller than $5 \mathrm{~Hz}$ can be affected by aliasing effects (Smalley, 2009) we compared the results with strong motion data which are independent and not affected by aliasing due to their high sampling rates.

PPP GPS time series contain both systematic errors (e.g. multipath) and unmodeled stochastic noise, which can be the same order of magnitude of the seismic signal. We applied an ad-hoc strategy in order to minimize the noise level of the position time series. In order to reduce the uncertainties we combined the GPS PPP solutions originating from different processing software. In particular, we used GIPSY 6.2 (Zumberge et al., 1997; Webb and Zumberge, 1997) and CSRS-PPP (http://webapp.geod.nrcan.gc.ca/geod/) to process the GPS data in kinematic mode. In all approaches we used the final IGS products (precise reference orbit and clock products), a $10^{\circ}$ satellite elevation mask angle and the ITRF08 (Altamimi et al., 2011) as reference frame. The two kinematic time series from the different processing were filtered by using the modified sidereal filtering technique (Fig. 2; Choi et al., 2004), and aligned subtracting the mean values for the period prior to the event. An editing criterion has been adopted in order to eliminate high residuals by taking, for each couple of solutions the weighted mean value with the inverses of estimated variances as weights. This choice of weighting always assures an increasing in precision. Indeed, for two measurements $x_{1}$ and $x_{2}$ with standard deviations of $\sigma_{1}$ and $\sigma_{2}$ respectively, the quantity

$$
y=\frac{\sigma_{2}^{2} \cdot x_{1}+\sigma_{1}^{2} \cdot x_{2}}{\sigma_{1}^{2}+\sigma_{2}^{2}}
$$

has a propagated error of $\sigma_{y}=\frac{\sigma_{1} \cdot \sigma_{2}}{\sqrt{\sigma_{1}^{2}+\sigma_{2}^{2}}}$ which is always $\leq \min \left(\sigma_{1}, \sigma_{2}\right)$. We checked that for the considered periods all the solutions from the two processing were compatible.

\section{DISPLACEMENT DATA ANALYSIS}

We analyzed the processed displacements in the frequency domain to characterize the noise components that affect the GPS time series. As for many geophysical phenomena and following Mao et al. (1999), the power spectral density (PSD) of a GPS displacement time series can be well modeled as the sum of white noise $(k=0)$ and colored noise (timecorrelated) of the form:

$P S D=P_{0}\left(f^{-k}+f_{0}^{-k}\right)$

where $f_{0}$ represents the crossover frequency of the PSD where the two processes have the same power levels. At frequencies higher than $f_{0}$ the signal components are indistinguishable from the white noise, thus losing any information. We adopted the Welch's method (Welch, 1967) to estimate the PSD by using 12 hours of data not including the earthquakes. We used the Levenberg-Marquardt algorithm (LMA) (Marquardt, 1963) to estimate the model parameters. Figure 3 shows that the analyzed GPS time series follow a Brownian/red noise behavior and that the crossover frequency is higher for $5 \mathrm{~Hz}$ data. This means an improvement in resolving and tracking the higher frequency ground shaking typical of earthquakes. For the first event of Jan 26, we had the possibility to process GPS data sampled at $5 \mathrm{~Hz}$. We adopted the same processing scheme, obtaining the solutions in Figure 4 where the time series at $5 \mathrm{~Hz}$ is compared with the one obtained from the data at $1 \mathrm{~Hz}$. 

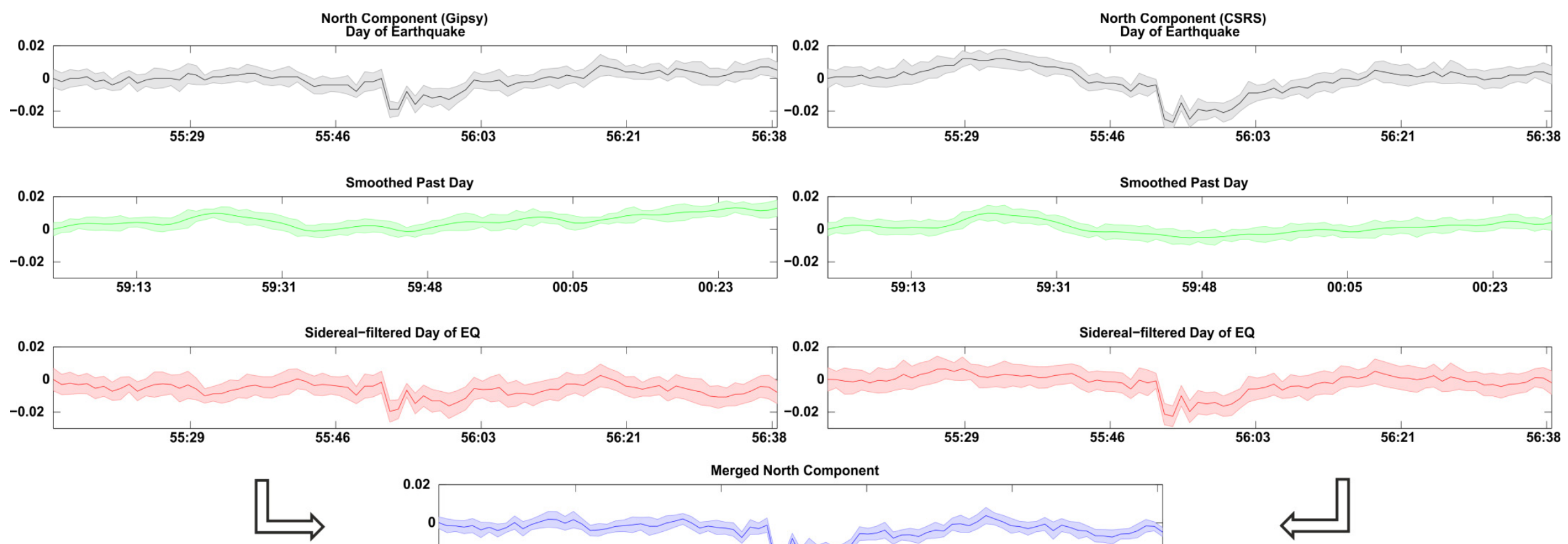

Sidereal-filtered Day of EQ

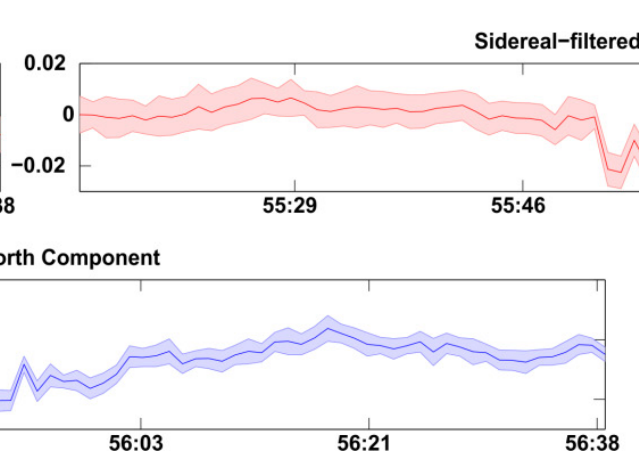

Fig. 2 Time series of high-rate GPS solution enhancement by using a sidereal filtering and a weighted merging. For each raw time series of the North component of GPS solutions a sidereal filter was applied to reduce the dynamics due to multipath effects. The filtered signals are then merged by a weighted mean. $\mathrm{X}$-axis is minutes: seconds of day 26, year 2014. Y-axis is in metres. 

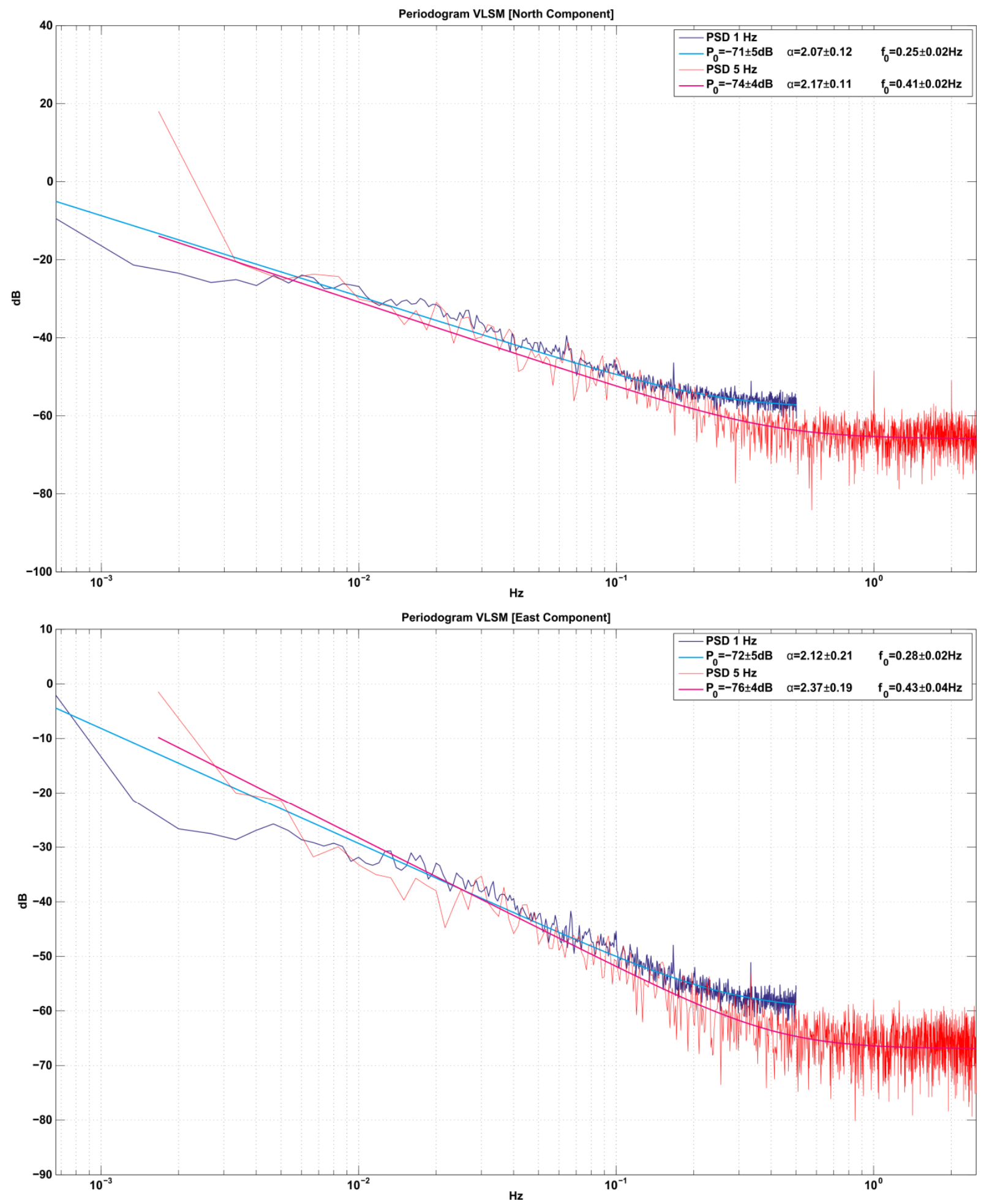

Fig. 3 Power spectral density for the horizontal components of displacement time series for data at $1 \mathrm{~Hz}$ (in blue) and $5 \mathrm{~Hz}$ (in red). The stochastic noise has been modeled with a sum of colored noise and white noise (in cyan for $1 \mathrm{~Hz}$ data and purple for $5 \mathrm{~Hz}$ data) as in Eq. (2) and the model parameters have been estimated by LMA. The estimated crossover frequency is higher for the $5 \mathrm{~Hz}$ data $\left(f_{0}=0.6 \mathrm{~Hz}\right.$ against $f_{0}=0.2 \mathrm{~Hz}$ for $1 \mathrm{~Hz}$ data) thus confirming an improvement, due to the higher sampling frequency, in detecting the higher frequency dynamics that characterize an earthquake. 


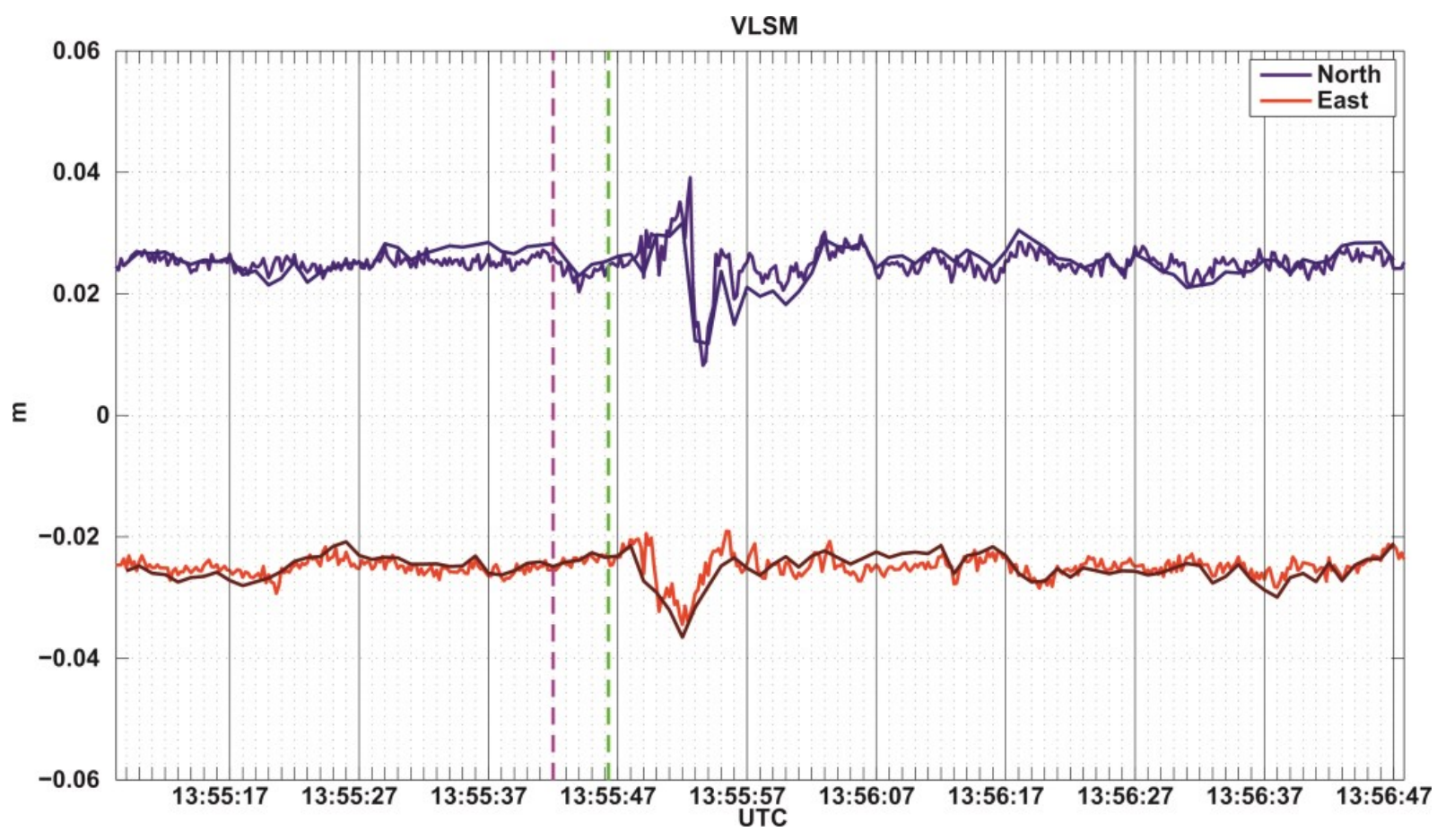

Fig. 4 Final GPS time series for station VLSM at $1 \mathrm{~Hz}$ (in dark red for East component and in dark blue for North component) and at $5 \mathrm{~Hz}$ (in light red for East component and in light blue for North component). The vertical dashed purple line marks the Jan 26 earthquake time, while the dashed green line marks the $\mathrm{P}$-wave arrival time at VLSM station.

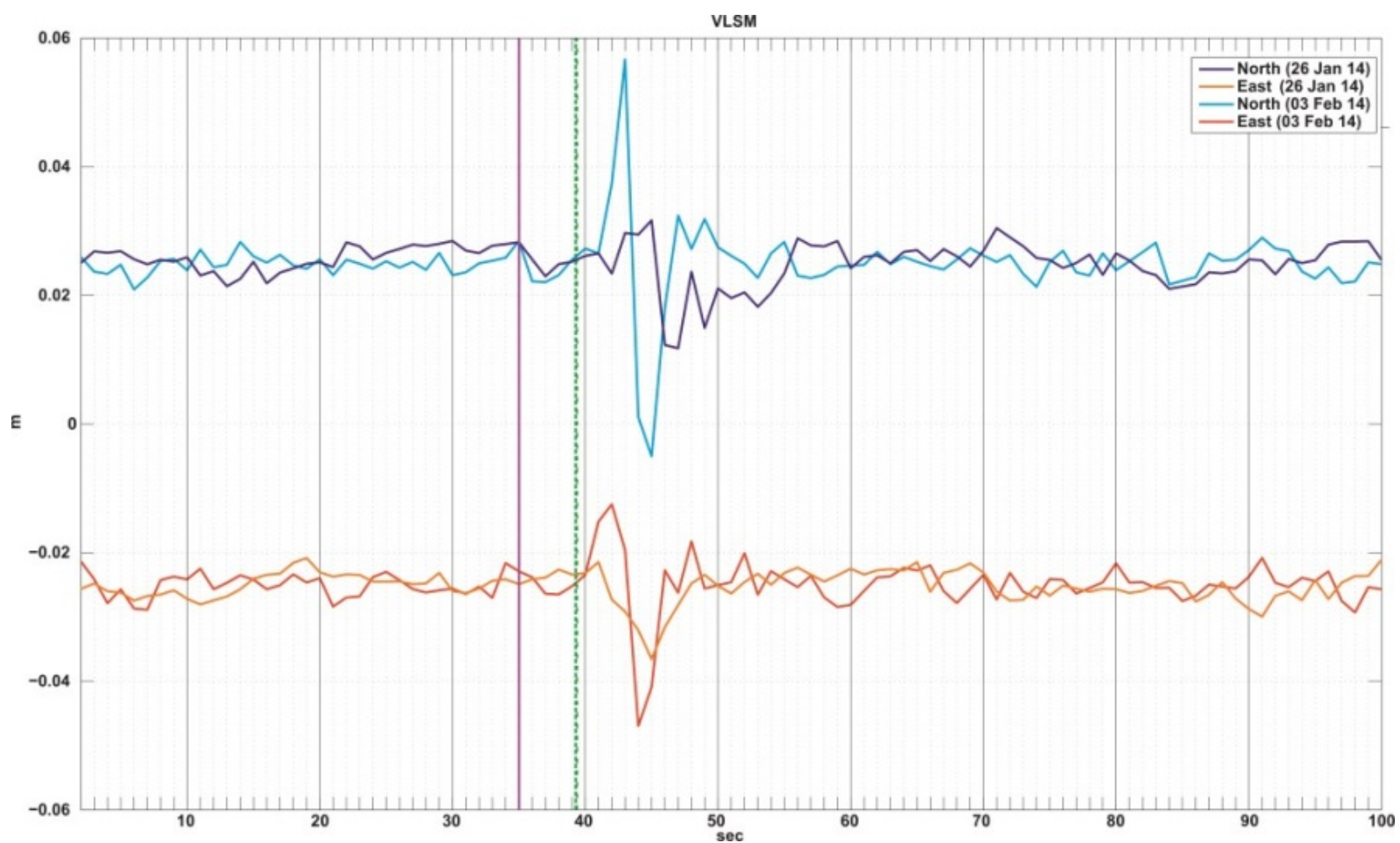

Fig. 5 Comparison between the 1-Hz GPS time series at VLSM station for the two events. The purple line is the time of the earthquakes, while the dark green dotted line shows the P-wave arrival for the Jan 26 event and the light green dotted line the P-wave arrival for the Feb 3. event. 
Table 1 Focal parameters of the two strong earthquakes of the January-February 2014 Cephalonia seismic sequence as calculated by Karastathis et al. (2014). Moment magnitude is from NOA http://bbnet.gein.noa.gr/HL/seismicity/moment-tensors .

\begin{tabular}{llllcl}
\hline $\begin{array}{l}\text { Date } \\
(\text { DD.MM.YYYY) }\end{array}$ & $\begin{array}{l}\text { Time } \\
\text { (UTC) }\end{array}$ & $\begin{array}{l}\text { Latitude } \\
\text { (degrees) }\end{array}$ & $\begin{array}{l}\text { Longitude } \\
\text { (degrees) }\end{array}$ & $\begin{array}{l}\text { Depth } \\
(\mathrm{km})\end{array}$ & $\begin{array}{l}\text { Magnitude } \\
\text { Mw }\end{array}$ \\
\hline 26.01 .2014 & $13: 55: 42$ & 38.2102 & 20.4614 & 16 & 6.0 \\
03.02 .2014 & $03: 08: 44$ & 38.2734 & 20.4310 & 5 & 5.9 \\
\hline
\end{tabular}

The different amplitudes in the ground motion between the two events can be also seen from Figure 5 where the time series at the same station are compared. In particular, we estimated the peak-topeak motion obtaining for the 2014, Jan 26 event a maximum dynamic displacement in the North component of $3.0 \mathrm{~cm}$ and $1.5 \mathrm{~cm}$ in the East component, while for the 2014, Feb 3 event we estimated the maximum displacement of $6.1 \mathrm{~cm}$ and $3.4 \mathrm{~cm}$ in the North and East components respectively. Hence the second earthquake, even if with almost $22 \%$ less seismic moment in comparison to the first, produced a ground displacement double in amplitude. This could be explained by a difference in focal depth between the two events (Table 1; 15 vs. $5 \mathrm{~km}$ ) despite the difference in epicentral distance (11 vs. $18 \mathrm{~km}$ ), or to a difference in rupture dynamics or to a combination of both processes. Also, the azimuth from seismic event to GPS station is different in the two cases (Fig. 1).

\section{COMPARISON BETWEEN STRONG MOTION AND HIGH-RATE GPS TIME SERIES}

We compared the time series of the displacement estimated by GPS at station VLSM and the displacement integrated from the accelerometer at SMHA (NOA) station which is located $9.7 \mathrm{~km}$ to the NE (location Sami; see Fig. 1). The raw accelerometer data have been a) corrected for the sensor CMG-5TD response and b) integrated, following the procedure described in Boore et al. (2002). Figure 6 shows the comparative behavior on the ground shaking (both amplitude and shape of waveforms) and the time delay (2-3 seconds) due to the different location with respect to the epicentre of the earthquake. The difference in S-wave (identified by the accelerometric signal) amplitude between the two earthquakes is confirmed also by the strong motion data. The calculated cross-correlation coefficients, also displayed in Figure 6, quantify the good agreement between the two observations especially for the second event.

\section{30-S DATA PROCESSING}

We analysed daily 30-s observations from four (4) continuously operating stations within $100 \mathrm{~km}$ from the epicentres of the two strong events using GAMIT/GLOBK 10.40 (Herring et al., 2010). We used precise orbits from the International GNSS Service (IGS) and absolute calibration values from IGS tables, adopting a three step approach based on the «quasi-observation» theory (Feigl et al., 1993; Dong et al., 1998). For more details regarding the processing strategy as well as the reference frame realization, the reader is referred to Chousianitis et al. (2013). The final product of the analysis is the threecomponent time series of daily station positions with respect to the IGS realization of the ITRF2008 NNR frame (Altamimi et al., 2011). The North, East and Up detrended position time series of the VLSM GPS station affected by the Cephalonia seismic events are depicted in Figure 7 for time periods from January 1, 2013 until February 15, 2014. The static coseismic displacements were estimated by calculating the difference between the average position of 7 days before, and the average position of 7 days after the events on January 26, 2014 and February 3, 2014. The coseismic offsets are reported in Table 2 for all stations analysed (including station KEFA reported at the web site http://dionysos.survey.ntua.gr/ and station SVOR provided by the HEPOS network operators). The vector norms are plotted in Figure 8. The displacement of station KIPO was calculated from 30s data up to day 255 of 2013 (Sep 12, 2013) and after day 36 of 2014 (Feb 5, 2014). Therefore, its static offset includes both seismic events without knowing which event caused most of it or which was the azimuth of the static motion for each event.

\section{DISCUSSION AND CONCLUSIONS}

Cephalonia has been repeatedly subjected to strong ground shaking due to the proximity of the island to the Cephalonia transform fault (CTF; Fig. 8; Scordilis et al., 1985; Tselentis et al., 1997; Louvari et al., 1999; Sachpazi et al., 2000; Qi Cheng et al., 2007). The 100-km long fault zone accommodates the relative motion of the Apulia (Africa) and Aegean (Eurasia) lithospheric plates with a 70-85 km cumulative dextral displacement (Pearce et al., 2012). Part of this relative motion is accommodated by a significant thrust component as it is evidenced by onshore geological data (Lekkas et al., 2001). Our 30-s GPS data provide important constraints to identify the seismic sources of the Jan-Feb 2014 earthquakes and to associate them with the CTF itself or not. 

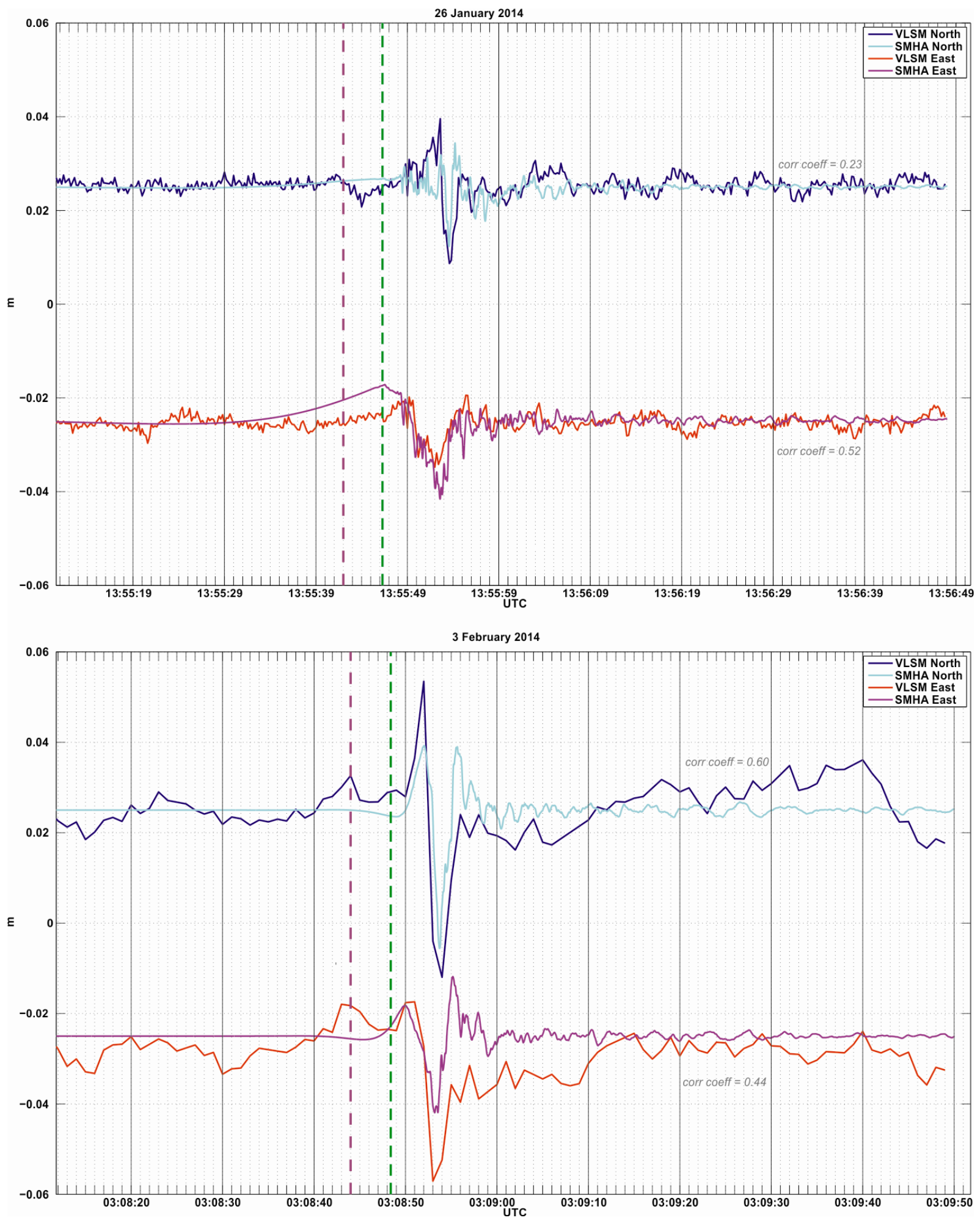

Fig. 6 Comparison between the displacement at VLSM station estimated by GPS and strong motion estimated at SMHA station by an accelerometer, for the two earthquakes. The time series are aligned with the occurrence of the earthquake. Cross-correlation coefficients are also displayed. 

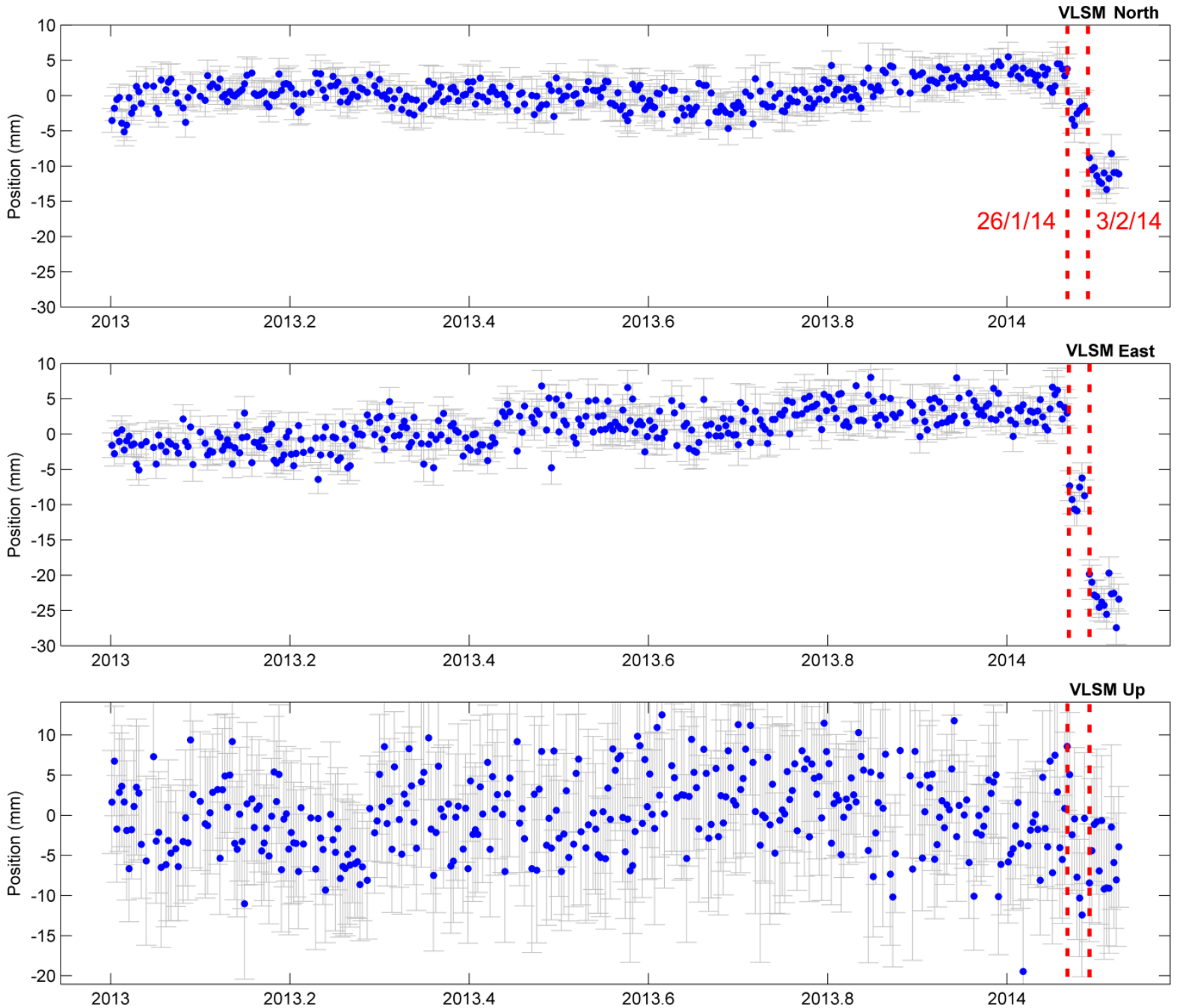

Fig. 7 Detrended time series (North, East, Up) of VLSM station with coseismic offsets processed with GAMIT. Two static offsets of $\mathrm{cm}$-size are clearly detected on the horizontal components for the days following the 2014 Cephalonia earthquakes. Both offsets are directed towards the south and west. Daily position uncertainties are indicated by grey error bars.

Table 2 Offset results from 30-s data for horizontal components of NOANET (VLSM, KIPO, PONT) and collaborative stations (AGRI; belongs to the private company METRICA SA; SVOR to HEPOS network). Station KEFA was provided by NTUA http://dionysos.survey.ntua.gr/ and belongs to the private company Tree Company SA. The norm displacement refers to the norm of the horizontal motion vector. For station location see map in Figures 1, 8, 9.

\begin{tabular}{|c|c|c|c|c|c|c|c|c|c|}
\hline Station & LAT & LON & $\begin{array}{c}1^{\text {st }} \text { Event } \\
\mathrm{N} \\
\mathrm{cm}\end{array}$ & $\begin{array}{c}1^{\text {st }} \text { Event } \\
\mathrm{E} \\
\mathrm{cm}\end{array}$ & $\begin{array}{c}2^{\text {nd }} \text { Event } \\
\mathrm{N} \\
\mathrm{cm}\end{array}$ & $\begin{array}{c}2^{\text {nd }} \text { Event } \\
\mathrm{E} \\
\mathrm{cm}\end{array}$ & $\begin{array}{c}1^{\text {st }} \text { Event } \\
\text { NORM } \\
\mathrm{cm}\end{array}$ & $\begin{array}{c}2^{\text {nd }} \text { Event } \\
\text { NORM } \\
\mathrm{cm}\end{array}$ & $\begin{array}{c}\text { TOTAL } \\
\text { NORM } \\
\mathrm{cm}\end{array}$ \\
\hline KIPO & 38.2030 & 20.3480 & $\mathrm{n} / \mathrm{a}$ & $\mathrm{n} / \mathrm{a}$ & $\mathrm{n} / \mathrm{a}$ & $\mathrm{n} / \mathrm{a}$ & $\mathrm{n} / \mathrm{a}$ & $\mathrm{n} / \mathrm{a}$ & 7.41 \\
\hline VLSM & 38.1768 & 20.5886 & -0.52 & -1.05 & -0.90 & -1.55 & 1.17 & 1.80 & 2.97 \\
\hline PONT & 38.6189 & 20.5851 & -0.05 & -0.24 & -0.06 & -0.26 & 0.24 & 0.38 & 0.60 \\
\hline AGRI & 38.6240 & 21.4090 & -0.09 & -0.07 & -0.06 & -0.11 & 0.11 & 0.13 & 0.24 \\
\hline KEFA & 38.1960 & 20.4380 & -4.70 & 2.50 & -20.00 & 0 & 5.30 & 14.00 & 19.30 \\
\hline SVOR & 38.1149 & 20.5228 & -1.20 & 0.5 & $\mathrm{n} / \mathrm{a}$ & $\mathrm{n} / \mathrm{a}$ & 1.30 & $\mathrm{n} / \mathrm{a}$ & $\mathrm{n} / \mathrm{a}$ \\
\hline
\end{tabular}




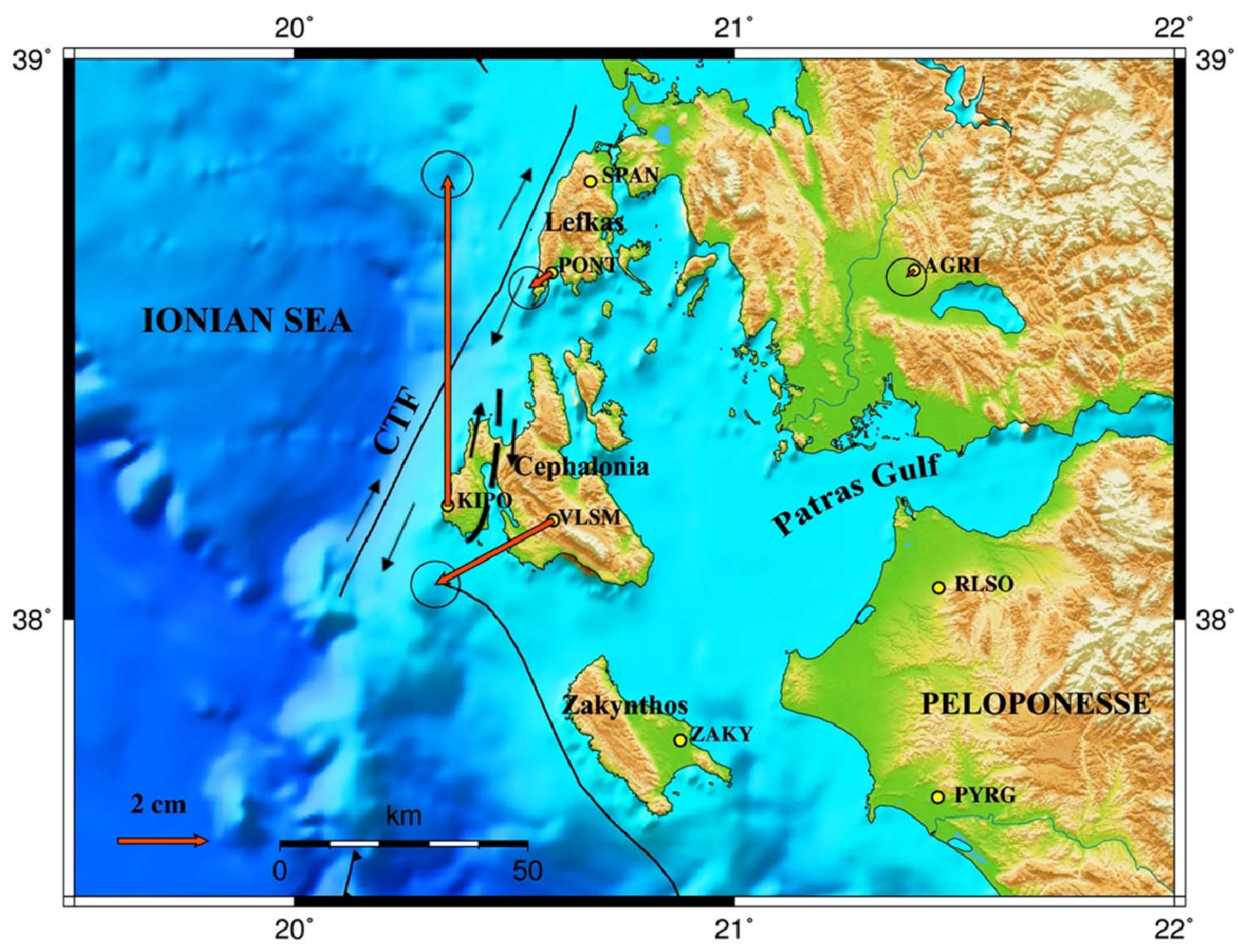

Fig. 8 Map of central Ionian area, Greece with displacement vectors of four GPS stations (KIPO, VLSM, PONT, AGRI).

Results for 30-s data are shown for the period before Jan 26 and after Feb 3, 2014 Combined static offsets for horizontal components are reported in Table 2. Dark red N-S line indicates crustal block boundary with inferred sense of motion from geodesy. 
Table 3 Source parameters used for horizontal displacement modeling at Earth's surface by use of software Coulomb v3.3 (Toda et al., 2011).

\begin{tabular}{|c|c|c|c|c|c|c|c|c|c|c|c|}
\hline \multirow{2}{*}{$\begin{array}{l}\text { Lon } \\
\left({ }^{\circ}\right)\end{array}$} & \multirow{2}{*}{$\begin{array}{l}\text { Lat } \\
\left({ }^{\circ}\right)\end{array}$} & \multirow{2}{*}{$\begin{array}{c}\text { Fault length } \\
(\mathrm{km}) \\
\text { Fault width } \\
(\mathrm{km})\end{array}$} & \multirow{2}{*}{$\begin{array}{c}\begin{array}{c}\text { Fault top } \\
(\mathrm{km})\end{array} \\
\text { Bottom } \\
(\mathrm{km})\end{array}$} & \multirow{2}{*}{$\begin{array}{c}\text { Depth } \\
(\mathrm{km})\end{array}$} & \multicolumn{4}{|c|}{ Source NOA } & \multirow{2}{*}{$\begin{array}{c}\begin{array}{c}\text { Slip RL } \\
\text { (m) }\end{array} \\
\text { Slip Rev } \\
\text { (m) }\end{array}$} & \multirow[t]{2}{*}{ Poisson } & \multirow{2}{*}{$\begin{array}{c}\mathrm{E} \\
\text { (bar) }\end{array}$} \\
\hline & & & & & $M_{w}$ & $\begin{array}{c}\text { Strike } \\
\left({ }^{\circ}\right)\end{array}$ & $\begin{array}{c}\text { Dip } \\
\left({ }^{\circ}\right) \\
\end{array}$ & $\begin{array}{c}\text { Rake } \\
\left({ }^{\circ}\right)\end{array}$ & & & \\
\hline 20.461 & 38.210 & $13.2 / 7.9$ & $9.2 / 16.5$ & 16.5 & 6.0 & 18 & 67 & 164 & $\begin{array}{c}0.381 / \\
0.109\end{array}$ & 0.25 & $8 \mathrm{E}+05$ \\
\hline
\end{tabular}

The 30-s GPS data analysis shows that station VLSM moved to the SW while station KIPO moved to the $\mathrm{N}$ (Fig. 8). This motion pattern is in agreement with the right-lateral kinematics for both ruptures as obtained from seismology (moment tensor solutions). Furthermore, the spatial distribution of the relocated earthquake sequence (Karastathis et al., 2014) indicates that the earthquake activity covers only the western part of Cephalonia Island trending from NNE to SSW at a length of about $35 \mathrm{~km}$ and maximum lateral width of c. $10 \mathrm{~km}$. In that paper, the source of seismicity clearly differs from that of CTF. This combination of evidence (GPS and seismic) clearly suggests that the Jan 26 and Feb 3, 2014 earthquakes occurred on near-vertical, strike-slip faults to the east of station KIPO, i.e. the activated fault segments are located on-shore Cephalonia. The geodetic result (Fig. 8) also confirms, that a N-S seismic fault zone has been activated onshore Cephalonia, in agreement with the InSAR findings from Merryman-Boncori et al. (2015). The northward motion of station KIPO implies that the western peninsula of Cephalonia island (Paliki) belongs to a separate crustal block with respect to the rest of the island. We need more geodetic data to identify the borders of this block; however it is likely that it runs North-South (as it is traced in Figure 8; see dashed black line) because of the interseismic pattern of campaign GPS velocities published by Lagios et al. (2012).

To test this N-S boundary scenario we computed a forward, Okada-type model (Okada, 1992; see Table 3 for parameters) for a buried dislocation in elastic half-space, using the NOA moment tensor (MT) solution for the 2014, Jan 26, 2013 event (http://bbnet.gein.noa.gr/HL/seismicity/moment-

tensors ). The dislocation strikes $\mathrm{N} 18^{\circ} \mathrm{E}$, dips $67^{\circ}$ to the east and it is found at depths from $9.2 \mathrm{~km}$ (top fault) to $16.5 \mathrm{~km}$ (bottom fault). The hypocentre is placed at the depth of $16.5 \mathrm{~km}$ according to Karastathis et al. (2014). Our 2014, Jan 26 surface deformation model compares well with the continuous GPS observations (see Fig. 9) for comparison with observed displacements), although all GPS data are located at the hanging wall of the 2014, Jan 26 fault. Our continuous GPS stations data (observed offsets) are reported in Table 2 including NOANET stations VLSM and PONT, one private-company station
(KEFA) and one station from the HEPOS network (http://www.hepos.gr/; their station 040A renamed SVOR in this paper), in total four (4) stations in operation during the first event. Irrespective of the fault location used in modeling (Fig. 9) it is evident that a general N-S pattern of surface displacement vectors has appeared on either side of the hypocentre (yellow star in Fig. 9).

In addition, a fault source towards the southwest of the hypocentre (Fig. 9a) fits better the observed surface displacements, as motion vectors of VLSM \& SVOR fit very well the modeled ones (Figs. 9b and 9c show rupture locations to the north and in the middle of the hypocentre, respectively). Station KEFA shows a large residual, probably due to local site effects as this station is located inside the town of Lixouri (Fig. 1) where liquefaction phenomena were observed (Valkaniotis et al., 2014; Papadopoulos et al., 2014). Our rupture model considers a single fault slip patch (with slip partitioning parameters as in Table 3). In Figure 9 we model the first earthquake source as oneand two-directional, meaning that the location of the hypocentre (start of the rupture) is at the ends or in the middle of the rupture. This affects the Okada calculations in 3-D space. It has to be clarified that when considering different rupture models, the position of the fault is not the same, as it can be seen in Figures 9a, 9b, and 9c. In the case of Figure 9a the position of the fault is more southerly than in the case of Figure 9c (a two-directional rupture). Both the position of the fault and the one- and two-directional slip patterns are taken up for the seismic moment calculations producing the three different theoretical displacement fields seen in Figure 9. This modeling could not be repeated for the $2^{\text {nd }}$ event as there are several MT solutions proposing an east-dipping strike slip fault, however, we cannot exclude a west-dipping fault plane on the basis a) of the GFZ MT solution published on the EMSC site, b) the seismicity relocation by Karastathis et al., (2014) and c) the InSAR motion pattern (Merryman Boncori et al., 2015).

The Jan - Feb 2014 earthquakes highlighted the need for more seismological and geophysical data both onshore and offshore Cephalonia, to locate and map active faults including CTF fault structure (e.g. is it one offshore segment or several?) and its relation to 


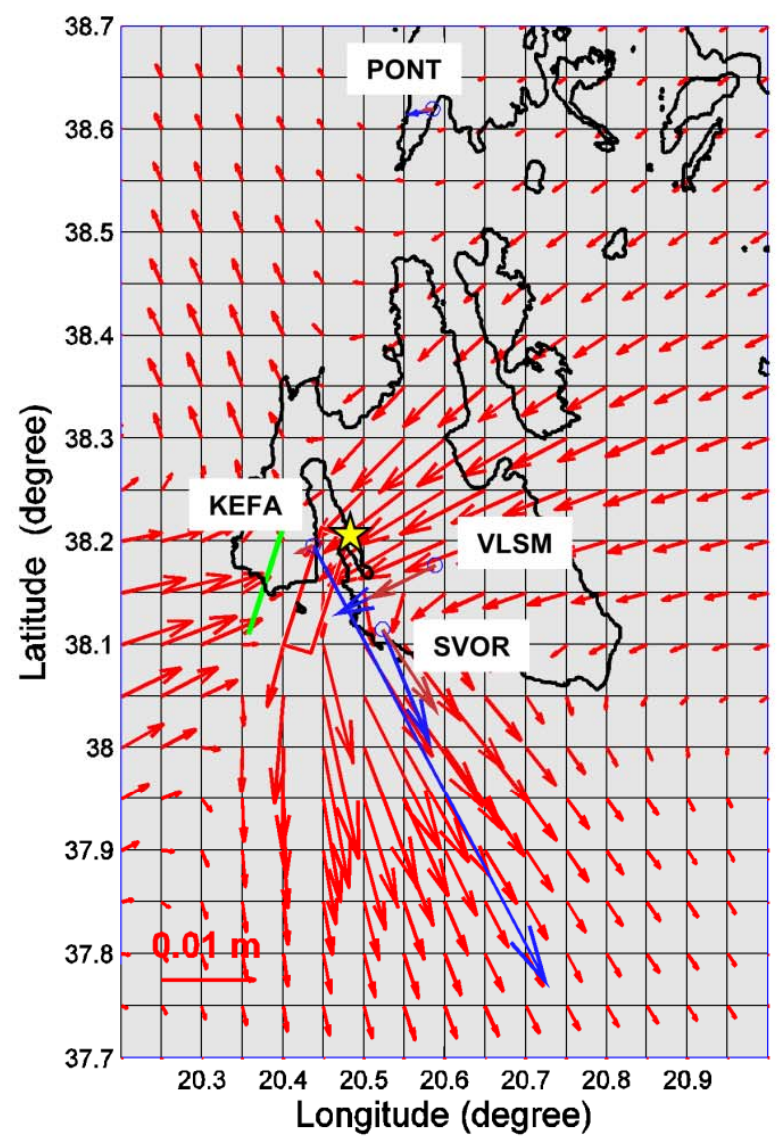

(a)

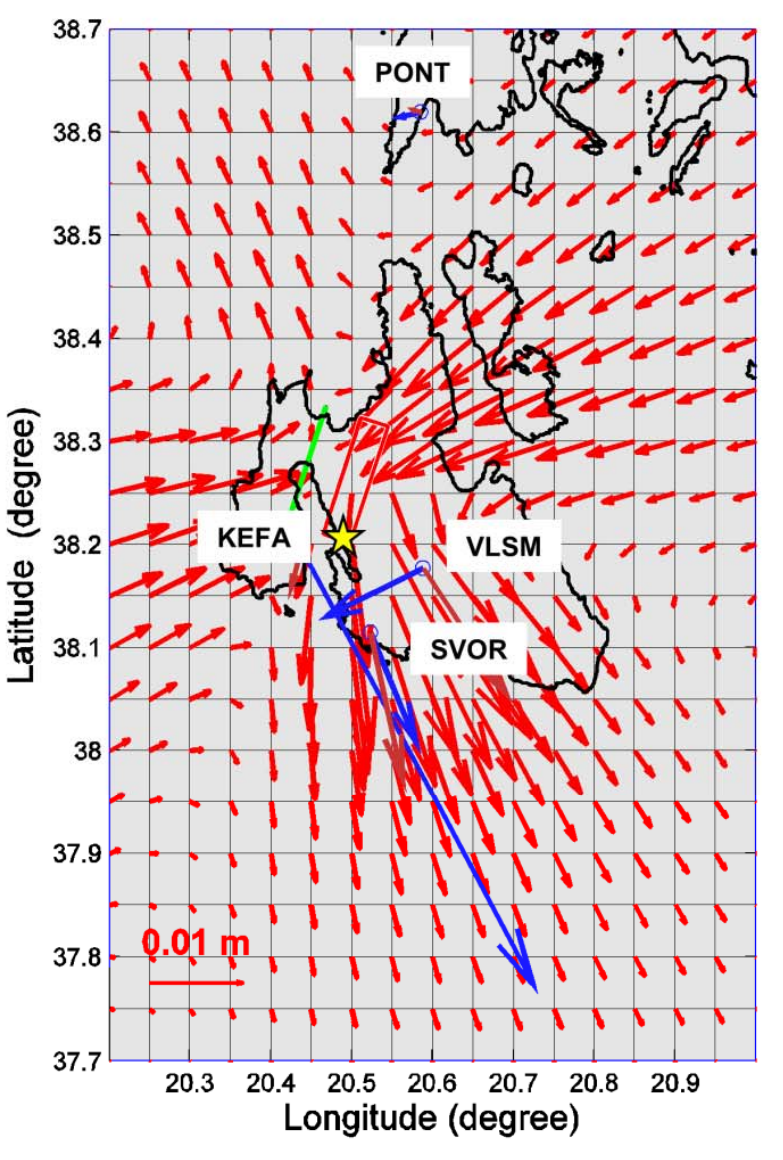

(b)

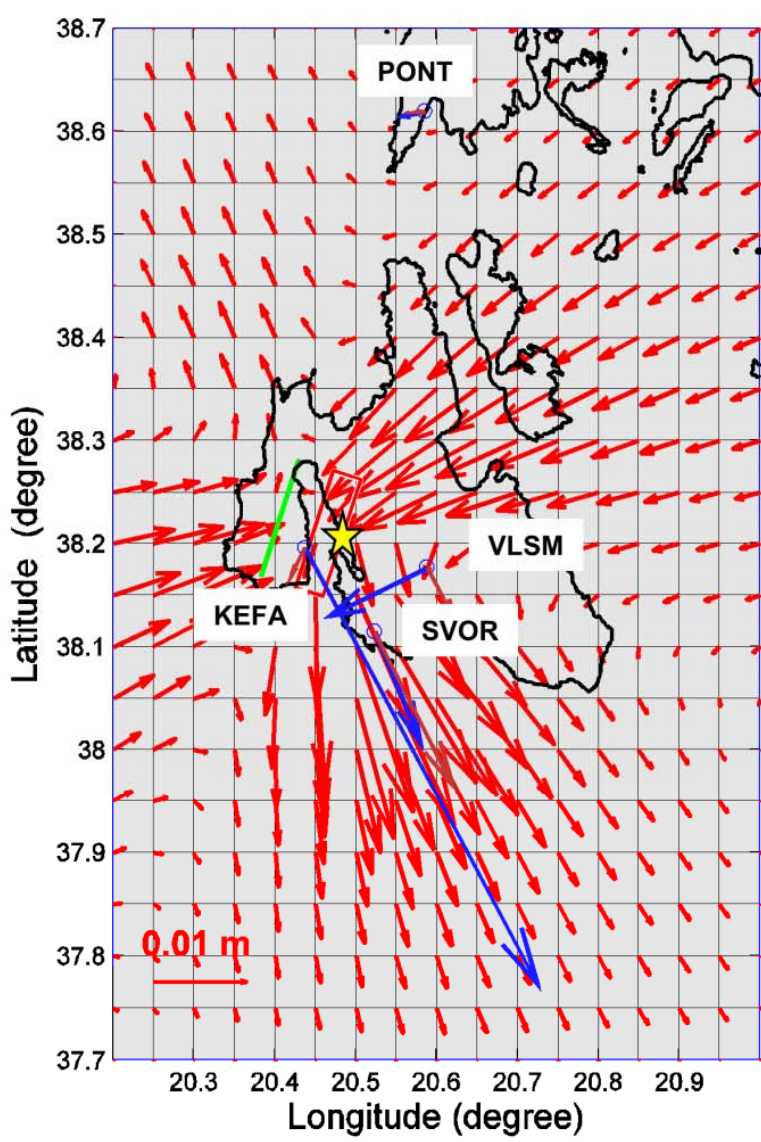

(c)

Fig. 9 Maps showing Okada-type dislocation models for horizontal displacement at ground surface regarding the Jan 26, 2014 earthquake compared to coseismic CGPS measurements (stations VLSM, KEFA, PONT and SVOR) a) for whole fault rupture towards the south of the hypocentre b) fault rupture on either side of the hypocentre and c) for whole fault rupture towards the north of the hypocentre. Blue is observed, red is modeled. Surface deformation is calculated over a $0.05^{\circ} \times 0.05^{\circ}$ grid. Rectangles indicate the surface projection of the seismic fault. Green line is fault projection at surface. Source parameters are as in Table 3 . 
the large offshore scarp about $10 \mathrm{~km}$ to the west of Cephalonia (see Fig. 1 for its location). This data is also necessary to characterize the seismic potential of this plate boundary fault by estimating the area and percentage of seismic coupling along it trace. Previous work from seismic profiles (Sachpazi et al., 2000; Kokkinou et al., 2005) locate the CTF within 10-km to the west of Cephalonia, however, the 2014 seismicity is offset eastwards with respect to the CTF trace. The northward motion of NOA station KIPO implies that CTF did not rupture during the 2014 events, because KIPO is located at the hanging wall of CTF and its expected co-seismic motion is to the south (CTF is a dextral strike-slip fault dipping to the southeast; Louvari et al., 1999). Therefore, it follows that CTF is accumulating elastic strain since 1983 $(M w=6.8$, Global CMT solution; Scordilis et al., 1985) with an average slip rate of $2 \mathrm{~cm} / \mathrm{yr}$ (Serpelloni et al., 2005; Vernant et al., 2014). Considering the scaling relations of Mai and Beroza (2000; relation mean slip to seismic moment) the amount of accumulated strain along CTF since 1983 can be released by a seismic event of M6.5-6.7, at any time.

\section{AUTHOR CONTRIBUTION}

F.C and K.C processed the Cephalonia GPS data. I.K did the Okada-type model. A.G wrote the manuscript with contributions from all co-authors

\section{ACKNOWLEDGEMENTS}

We thank two anonymous reviewers for constructive comments. We also thank Vassilios Karastathis, Stefano Salvi, Sotiris Valkaniotis, Efthimios Lekkas, Christodoulos Kyriakopoulos, Gerassimos Papadopoulos, Ioannis Papoutsis, Haris Kontoes, Michail Gianniou, Panagiotis Argyrakis, Marios Papanikolaou, Christina Tsimi, Alexandra Moshou and Maria Sachpazi for comments and discussions on various aspects of this work. We thank Ioannis Kalogeras for providing the accelerometric data for NOA station Sami and Michail Gianniou for co-seismic offsets from station SVOR. Figures 7 and 8 were made by use of GMT software; Figure 9 by use of Coulomb v3.3. Figure 1 was prepared by S. Valkaniotis. NOANET was funded by several EU FP6 \& FP7 projects, ESA and the Greek government (GSRT and project ASPIDA). NOANET data is available from www.gein.noa.gr/gps.html and the NOA GSAC http://194.177.194.238:8080/noanetgsac

\section{REFERENCES}

Altamimi, Z., Collilieux, X., and Métivier, L.: 2011, ITRF2008: an improved solution of the international terrestrial reference frame. Journal of Geodesy, 85(8), 457-473. DOI: 10.1007/s00190-011-0444-4

Avallone, A., Marzario, M., Cirella A., Piatanesi A., Rovelli A., Di Alessandro, C. et al.: 2011, Very high rate (10 $\mathrm{Hz})$ GPS seismology for moderate-magnitude earthquakes: The case of the Mw 6.3 L'Aquila (central Italy) event. Journal of Geophysical Research 116(B2). B02305. DOI: 10.1029/2010JB007834
Bilich, A., Cassidy, J.F., and Larson, K.M.: 2008, GPS seismology: Application to the $2002 \mathrm{Mw} 7.9$ Denali Fault earthquake. Bulletin of the Seismological Society of America, 98(2), 593-606. DOI: $10.1785 / 0120070096$

Bock, Y., Prawirodirdjo, L. and Melbourne, T.I.: 2004, Detection of arbitrarily dynamic ground motions with dense high-rate GPS network. Geophysical Research Letters, 31, L06604. DOI: 10.1029/2003GL019150

Boore, D.M., Stephens, C.D. and Joyner, W.B.: 2002, Comments on baseline correction of digital strongmotion data: Examples from the 1999 Hector Mine, California, earthquake. Bulletin of the Seismological Society of America, 92(4), 1543-1560. DOI: $10.1785 / 0120000926$

Canadian Spatial Reference System-Presice Point Positioning (CSRS-PPP) web page. URL:http://webapp.geod.nrcan.gc.ca/geod/toolsoutils/ppp.php

Choi, K., Bilich, A., Larson, K.M., and Axelrad, P.: 2004, Modified sidereal filtering: Implications for high - rate GPS positioning. Geophysical Research Letters, 31(22), L22608. DOI: $10.1029 / 2004 G L 021621$

Chousianitis, K., Ganas, A. and Gianniou, M.: 2013, Kinematic interpretation of present-day crustal deformation in central Greece from continuous GPS measurements. Journal of Geodynamics, 71, 1-13. DOI: 10.1016/j.jog.2013.06.004

Crowell, B. W., Bock, Y., and Melgar, D.: 2012, Real - time inversion of GPS data for finite fault modeling and rapid hazard assessment. Geophysical Research Letters, 39(9). DOI: $10.1029 / 2012$ GL051318

Daubechies, I.: 1990, The wavelet transform, timefrequency localization and signal analysis. IEEE Transactions on Information Theory, 36(5), 961-1005.

Dong, D.N., Herring, T.A. and King, R.W.: 1998, Estimating regional deformation from a combination of space and terrestrial geodetic data. Journal of Geodesy, 72, 200-214. DOI: 10.1515/JAG.2008.017

Ebner, R. and Featherstone, W.E.: 2008, How well can online GPS PPP post-processing services be used to establish geodetic survey control networks? Journal of Applied Geodesy, 2(3), 149-157. DOI: 10.1515/JAG.2008.017

Elósegui, P., Davis, J.L., Oberlander, D., Baena, R., and Ekström, G.: 2006, Accuracy of high - rate GPS for seismology. Geophysical Research Letters, 33, L11308. DOI: 10.1029/2006GL026065

Emore, G., Haase, J., Choi, K., Larson, K.M. and Yamagiwa, A.: 2007, Recovering seismic displacements through combined use of 1-Hz GPS and strong-motion accelerometers. Bulletin of the Seismological Society of America, 97, 357-378. DOI: $10.1785 / 0120060153$

Feigl, K.L., Agnew, D.C., Bock, Y., Dong, D.N., Donnellan, A., Hager, B.H., Herring, T.A.,Jackson, D.D., King, R.W., Larsen, S.K., Larson, K.M., Murray, M.H. and Shen, Z.K.: 1993, Measurement of the velocity field in central and southern California. Journal of Geophysical Research 98, 21667-21712.

Ganas, A, Chousianitis, K., Drakatos, G., Papanikolaou, M., Argyrakis, P., Kolligri, M., Petrou, P., Batsi, E. and Tsimi, Ch.: 2011, NOANET: High-rate GPS Network for Seismology and Geodynamics in Greece. 
Geophysical Research Abstracts, 13, EGU2011-4840.

Ganas, A., Marinou, A., Anastasiou, D., Paradissis, D., Papazissi, K., Tzavaras, P. and Drakatos, G.: 2013, GPS-derived estimates of crustal deformation in the central and north Ionian Sea, Greece: 3-yr results from NOANET continuous network data. Journal of Geodynamics, 67, 62-71.

DOI: $10.1016 /$ j.jog.2012.05.010

Ganas, A., Cannavò, F., González, P.J. and Drakatos, G.: 2014, The geodetic signature of the Jan 26, 2014 earthquake onshore Cephalonia, Greece, unpublished report http://www.gein.noa.gr/Documents/pdf/VLSM coseismic 26-1-2014 13 55 UTC.pdf

Ge, L., Han, S. and Rizos, C.: 2000, Multipath mitigation of continuous GPS measurements using an adaptive filter. GPS Solutions, 4(2), 19-30. DOI: $10.1007 /$ PL00012838

Genrich, J.F. and Bock, Y.: 2006, Instantaneous geodetic positioning with 10-50 Hz GPS measurements: Noise characteristics and implications for monitoring networks. J. Geophys. Res., 111, B03403. DOI: $10.1029 / 2005 J B 003617$

Grapenthin, R. and Freymueller, J. .: 2011, The dynamics of a seismic wave field: Animation and analysis of kinematic GPS data recorded during the 2011 Tohoku - Oki earthquake, Japan. Geophysical Research Letters, 38(18). DOI: 10.1029/2011GL048405

Guo, A., Wang, Y., Li, Z., Ni, S., Wu, W., Liu, G., Zheng, Y. and Simons, M.: 2013, Observation of core phase $\mathrm{ScS}$ from the Mw 9.0 Tohoku - Oki earthquake with high - rate GPS. Seismological Research Letters, 84(4), 594-599. DOI: 10.1785/0220120143

Hirahara, K., Nakano, T., Hoso, Y., Matsuo, S. and Obana, K.: 1994, An experiment for GPS strain seismometer. Proceedings of the Japanese Symposium on GPS, 1516.

Herring, T.A., King, R.W. and McClusky, S.: 2010, Documentation for the GAMIT/GLOBK GPS processing software release 10.4. Mass. Inst. of Technol., Cambridge.

Hollenstein, Ch., Müller, M.D., Geiger, A. et al: 2008, Crustal motion and deformation in Greece from a decade of GPS measurements, 1993-2003. Tectonophysics, 449, Nos. 1-4, 17-40. DOI: $10.1016 /$ j.tecto.2007.12.006

Hollenstein, Ch., Müller, M.D., Geiger, A. and Kahle, H.G.: 2008b, GPS-derived coseismic displacements associated with the 2001 Skyros and 2003 Lefkada earthquakes in Greece. Bulletin of the Seismological Society of America, 98, No. 1, 149-161. DOI: 10.1785/0120060259

Ji, C., Larson, K.M., Tan, Y., Hudnut, K.W. and Choi, K.: 2004, Slip history of the 2003 San Simeon earthquake constrained by combining $1-\mathrm{Hz}$ GPS, strong motion, and teleseismic data. Geophysical Research Letters, 31, L17608. DOI: 10.1029/2004GL020448

Karastathis, V.K., Mouzakiotis, E., Ganas, A. and Papadopoulos, G.A.: 2014, High-precision relocation of seismic sequences above a dipping Moho: the case of the January-February 2014 seismic sequence in Cephalonia Isl. (Greece). Solid Earth Discuss., 6, 2699-2733. DOI: 10.5194/sed-6-2699-2014

Kokinou, E., Kamberis, E., Vafidis, A., Monopolis, D., Ananiadis, G. and Zelelidis, A.: 2005, Deep seismic reflection data Greece: a new crustal model for the Ionian sea. Journal of Petroleum Geology, 28, No. 2, $81-98$.

Kouba, J.: 2003, Measuring seismic waves induced by large earthquakes with GPS. Studia Geophysica et Geodaetica 47, 741-755. DOI: 1023/A.1026390618355

Lagios, E., Papadimitriou, P., Novali, F., Sakkas, V., Fumagalli, A., Vlachou, K. and Del Conte, S.: 2012, Combined seismicity pattern analysis, DGPS and PSInSAR studies in the broader area of Cephalonia (Greece). Tectonophysics, 524-525, 43-58. DOI: $10.1016 /$ j.tecto.2011.12.015

Langbein, J. and Bock, Y.: 2004, High - rate real - time GPS network at Parkfield: Utility for detecting fault slip and seismic displacements. Geophysical Research Letters, 31, L15S20. DOI: 10.1029/2003GL019408

Larson, K. M.: 2009, GPS seismology. Journal of Geodesy, 83(3-4), 227-233. DOI: 10.1007/s00190-008-0233-x

Larson, K.M., Bodin, P. and Gomberg, J.: 2003, Using 1-Hz GPS data to measure deformations caused by the Denali fault earthquake. Science, 300, No. 5624, 1421-1424. DOI: 10.1126/science.1084531

Larson, K.M. and Miyazaki, S.: 2008, Resolving static offsets from high-rate GPS data: the 2003 TokachiOki earthquake. Earth, Planets and Space, 60, 801808.

Lekkas, E., Danamos, G. and Maurikas, G.: 2001, Geological structure and evolution of Kefallonia and Ithaki Islands. Bulletin of the Geological Society of Greece, XXXIV/1, 11-17.

Lou, Y., Zhang, W., Shi, C. and Liu, J.: 2014, High-rate (1$\mathrm{Hz}$ and $50-\mathrm{Hz}$ ) GPS seismology: Application to the $2013 \mathrm{Mw}$ 6.6 Lushan earthquake. Journal of Asian Earth Sciences, 79, 426-431. DOI: 10.1016/j.jseaes.2013.10.016

Louvari, E., Kiratzi, A.A. and Papazachos, B.C.: 1999, The CTF and its extension to western Lefkada Island. Tectonophysics, 308, 223-236.

Mai, P.M. and Beroza, G.C.: 2000, Source scaling properties from finite-fault-rupture models, Bulletin of the Seismological Society of America, 90, No. 3, 604615. DOI: $10.1785 / 0119990126$

Marquardt, D. W.: 1963, An algorithm for least-squares estimation of nonlinear parameters. Journal of the Society for Industrial \& Applied Mathematics, 11(2), $431-441$.

Mao, A., Harrison, C.G. and Dixon, T.H.: 1999, Noise in GPS coordinate time series. Journal of Geophysical Research: Solid Earth (1978-2012), 104(B2), 27972816. DOI: $10.1029 / 1998 J B 900033$

Melgar, D., Bock, Y. and Crowell, B.W.: 2012, Real - time centroid moment tensor determination for large earthquakes from local and regional displacement records. Geophysical Journal International, 188(2), 703-718. DOI: 10.1111/j.1365-246X.2011.05297.x

Merryman Boncori, J.P., Papoutsis, I, Pezzo, G., Tolomei, C., Atzori, S., Ganas, A., Karastathis, V., Salvi, S., Kontoes, CH. and Antonioli, A.: 2015, The February 2014 Cephalonia earthquake (Greece): 3D deformation feld and source modeling from multiple SAR techniques. Seismological Research Letters, 86, No. 1, 124-137. DOI: 10.1785/0220140126

Miyazaki, S., Larson, K.M., Choi, K., Hikima, K., Koketsu, K., Bodin, P., Haase, J., Emore, G. and Yamagiwa, A.: 2004, Modeling the rupture process of the 2003 
September 25 Tokachi-Oki (Hokkaido) earthquake using 1-Hz GPS data. Geophysical Research Letters, 31, L21603. DOI: 10.1029/2004GL021457

Ohta, Y., Meiano, I., Sagiya, T., Kimata, F. and Hirahara, K.: 2006, Large surface wave of the 2004 SumatraAndaman earthquake captured by the very long baseline kinematic analysis of 1-Hz GPS data. Earth, Planets and Space, 58, No. 2, 153-157. DOI: $10.1186 / \mathrm{BF} 03353372$

Okada, Y.: 1992, Internal deformation due to shear and tensile faults in a half-space, Bull. Seism. Soc. Am., 82, 1018-1040.

Papadopoulos, G.A., Karastathis, V.K., Koukouvelas, I., Sachpazi, M., Baskoutas, I., Chouliaras, G., Agalos, A., Daskalaki, E., Minadakis, G., Moshou, A., Mouzakiotis, A., Orfanogiannaki, K., Papageorgiou, A., Spanos, D. and Triantafyllou, I.: 2014, The Cephalonia, Ionian Sea (Greece), sequence of strong earthquakes of January-February 2014: a first report. Research in Geophysics, 4-5441, No. 1, 19-29. DOI: $10.4081 / \mathrm{rg} .2014 .5441$

Pearce, F. D., Rondenay, S., Sachpazi, M., Charalampakis, M. and Royden, L.H.: 2012, Seismic investigation of the transition from continental to oceanic subduction along the western Hellenic Subduction Zone. Journal of Geophysical Research, 117, B07306. DOI: $10.1029 / 2011$ JB009023.

Pérouse, E., Chamot-Rooke, N., Rabaute, A., Briole, P., Jouanne, F., Georgiev, I. and Dimitrov, D.: 2012, Bridging onshore and offshore present-day kinematics of Central and Eastern Mediterranean: implications for crustal dynamics and mantle flow. Geochemistry, Geophysics, Geosystems, 13, No. 9, Q09013. DOI: $10.1029 / 2012 \mathrm{GC} 004289$.

Qi Cheng, Ganas, A., Huang Furiong, Chen Yong and Drakatos, G.: 2007, Recurrence behaviours of earthquakes along the Kefallinia transform fault, Ionian Sea, Greece. Earthquake Research in China, 21(4), 409-419.

Sachpazi, M., Him, A., Clément, C., Haslinger, F., Laigle M., Kissling, E., Charvis, P., Hello,Y., Lépine, J.-C., Sapin, M. and Ansorge, J.: 2000, Western Hellenic subduction and Cephalonia transform: local earthquakes and plate transport and strain. Tectonophysics, 319, No. 4, 301-319. DOI: $10.1016 / \mathrm{S} 0040-1951(99) 00300-5$

Sato, M., Ishikawa, T., Ujihara, N., Yoshida, S., Fujita, M., Mochizuki, M. and Asada, A.: 2011, Displacement above the hypocenter of the 2011 Tohoku-Oki earthquake. Science, 332, No. 6036, 1395.

DOI: $10.1126 /$ science. 1207401

Scordilis, E.M., Karakaisis, G.F., Karakostas, B.G., Panagiotopoulos, D.G., Comninakis, P.E. and Papazachos, B.C.: 1985, Evidence for transform faulting in the Ionian Sea: the Cephalonia Island earthquake sequence of 1983. Pure Appl. Geophys., $123,388-397$

Serpelloni, E., Anzidei, M., Baldi, P., Casula, G. and Galvani, A.: 2005, Crustal velocity and strain-rate fields in Italy and surrounding regions: new results from the analysis of permanent and non-permanent GPS networks. Geophy. J. Int., 161(3), 861-880. DOI: $10.1111 /$ j.1365-246X.2005.02618.x

Shen, Z.K., Sun, J., Zhang, P., Wan, Y., Wang, M., Burgmann, R., Zeng, Y., Gan, W., Liao, H. and Wang, Q.: 2009, Slip maxima at fault junctions and rupturing of barriers during the 2008 Wenchuan earthquake. Nature Geoscience, 2, 718-724.

DOI: 10.1038/ngeo636

Shi, C., Lou, Y., Zhang, H., Zhao, Q., Geng, J., Wang, R., Fang, R. and Liu, J. 2010, Seismic deformation of the Mw8.0 Wenchuan earthquake from high-rate GPS observations. Advance in Space Research, 46, 228235. DOI: $10.1016 /$ j.asr.2010.03.006

Smalley, R.: 2009, High-rate GPS: How high do we need to go?. Seismological Research Letters, 80(6), 10541061. DOI: $10.1785 / \mathrm{gssrl} .80 .6 .1054$

Toda Shinji, Stein, R.S., Sevilgen, Volkan, and Lin, Jian: 2011, Coulomb 3.3 Graphic-rich deformation and stress-change software for earthquake, tectonic, and volcano research and teaching-user guide: U.S. Geological Survey Open-File Report 2011-1060, 63, available at http://pubs.usgs.gov/of/2011/1060/.

Tselentis, G-A., Melis, N.S., Sokos, E. and Beltas, P.: 1997, The winter 1991-1992 earthquake sequence at Cephalonia Island, Western Greece. Pure Appl. Geophys, 150, No. 1, 75-89.

DOI: $10.1007 / \mathrm{s} 000240050064$

Valkaniotis, S., Ganas, A., Papathanassiou, G. and Papanikolaou, M.: 2014, Field observations of geological effects triggered by the January-February 2014 Cephalonia (Greece) earthquakes.

Tectonophysics, 630, 3, 150-157. DOI: $10.1016 / j$.tecto.2014.05.012

Vernant, P., Reilinger, R. and McClusky, S.: 2014, Geodetic evidence for low coupling on the Hellenic subduction plate interface. Earth Planet. Sci. Lett., 385(C), 122 129. DOI:10.1016/j.epsl.2013.10.018

Wang, G.Q., Boore, D.M., Tang, G. and Zhou, X.: 2007, Comparisons of ground motions from collocated and closely spaced one-sample-per-second Global Positioning System and accelerograph recordings of the 2003 M 6.5 San Simeon, California, earthquake in the Parkfield region. Bulletin of the Seismological Society of America, 97, 76-90. DOI: $10.1785 / 0120060053$

Webb, F.H. and Zumberge, J.F.: 1997, An introduction to GIPSY/OASIS II. JPL Publication D-11088

Welch, P. D.: 1967, The use of fast Fourier transform for the estimation of power spectra: a method based on time averaging over short, modified periodograms. IEEE Transactions on Audio and Electroacoustics, 15(2), 70-73.

Wright,T.J., Houlié, N., Hildyard, M. and Iwabuchi, T.: 2012, Real-time, reliable magnitudes for large earthquakes from $1 \mathrm{~Hz}$ GPS precise point positioning: The 2011 Tohoku-Oki (Japan) earthquake. Geophysical Research Letters, 39(12), L12302. DOI: 10.1029/2012GL051894

Zumberge, J.F., Heflin, M.B., Jefferson, D.C., Watkins, M.M. and Webb, F.H.: 1997, Precise point positioning for the efficient and robust analysis of GPS data from large networks. Journal of Geophysical Research: Solid Earth (1978-2012), 102(B3), 5005-5017. DOI: $10.1029 / 96 J B 03860$ 